\title{
KORELASI ANTARA FAKTOR CURAH HUJAN DENGAN KEJADIAN DBD TAHUN 2010-2014 DI KABUPATEN KARANGANYAR
}

\author{
Correlation Between Rainfall Factors and DHF Events in 2010-2014 in \\ Karanganyar Regency
}

\author{
Arifatun Nisaa \\ Program Studi Perekam dan Informasi Kesehatan, FKM Univet BANTARA Sukoharjo \\ email: arifatun.nisaa@gmail.com
}

\begin{abstract}
Dengue hemorrhagic fever is still a public health problem and the incidence of the case was up and down erratically. One of the causes of DHF incidence is rainfall. Based on geographic location and topography, Karanganyar Regency has temperature temperature between 180310C, the lowest temperature is in Tawangmangu Subdistrict when rainy season is 180C, while in Gondangrejo and Colomadu District reaches 310C. Aedes aegypti mosquitoes can survive at a temperature of 22 - 240C. In the rainy season, usually the incidence of dengue cases tends to increase. Based on data from 6 measuring stations in Karanganyar District, the number of rainy days during the year was 115.6 days with an average of 7,231.4 $\mathrm{mm}$ rainfall, where the highest rainfall occurred in February to April, while the lowest was at August and September. This study was an observational analytic study with multiple temporal analyzes. Data used in this research are secondary data of DBD case and rainfall factor data. Dengue fever spreads in residential areas. The strength of rainfall correlation with dengue is strong ( $r=0.62)$. There is no significant correlation between rainfall factor and DHF. This may be due to the lack of duration of data taken, incomplete physical factor data and the influence of other dominant factors.
\end{abstract}

Keywords: DHF, environmental dynamics, multi temporal analysis, spatial, GIS

\begin{abstract}
Abstrak
Demam berdarah dengue masih jadi masalah kesehatan masyarakat dan kejadian kasusnya pun naik turun tak menentu. Salah satu penyebab kejadian DBD adalah curah hujan. Berdasarkan letak geografi dan topografi, Kabupaten Karanganyar memiliki temperatur suhu antara $18^{0}-31^{\circ} \mathrm{C}$, Suhu terendah berada di wilayah Kecamatan Tawangmangu bila musim penghujan, yaitu $18^{\circ} \mathrm{C}$, sedangkan di wilayah Kecamatan Gondangrejo dan Kecamatan Colomadu mencapai suhu $31^{\circ} \mathrm{C}$. Nyamuk Aedes aegypti mampu bertahan pada suhu $22-24^{\circ} \mathrm{C}$. Pada musim hujan, biasanya kejadian kasus DBD cenderung meningkat. Berdasarkan data dari 6 stasiun pengukur yang ada di Kabupaten Karanganyar, banyaknya hari hujan selama setahun adalah 115,6 hari dengan rata-rata curah hujan 7.231,4 mm, dimana curah hujan tertinggi terjadi pada bulan Februari sampai dengan bulan April, sedangkan yang terendah pada bulan Agustus dan bulan September. Jenis penelitian ini adalah penelitian observasional analitik dengan multi temporal analisis. Data yang digunakan dalam penelitian ini berupa data sekunder kasus DBD dan Arifatun Nisaa adalah Program Studi Perekam dan Informasi Kesehatan, FKM Univet BANTARA Sukoharjo
\end{abstract}


data faktor curah hujan. Sebaran kasus DBD mengelompok di wilayah pemukiman. Kekuatan korelasi curah hujan dengan DBD adalah kuat $(\mathrm{r}=0,62)$. Tidak ada korelasi yang signifikan antara faktor curah hujan dengan DBD. Hal ini mungkin disebabkan oleh, kurang lamanya durasi data yang diambil, kurang lengkapnya data faktor fisik yang diperoleh dan adanya pengaruh dari faktor-faktor lain yang lebih dominan.

Kata kunci: DBD, dinamika lingkungan, multi temporal analisis, spasial, GIS

\section{PENDAHULUAN}

Indonesia merupakan salah satu negara yang beriklim tropis. iklim tropis ini hanya memiliki dua musim yaitu musim penghujan dan juga musim kemarau. Disaat pergantian musim kemarau ke musim penghujan merupakan waktu dimana terjadinya perkembangbiakan nyamuk. Pemberantasan penyakit ini terus menerus diupayakan untuk mengurangi angka kematian. Namun, kejadian kasus DBD naik turun tak menentu dari tahun ke tahun.

Menurut Barera et al. (2006), faktor lingkungan yang berpengaruh terhadap kehidupan vektor adalah faktor abiotik dan biotik. Faktor abiotik seperti curah hujan, temperatur, dan evaporasi dapat mempengaruhi kegagalan telur, larva dan pupa nyamuk menjadi imago. Keberhasilan itu juga ditentukan oleh kandungan air kontainer seperti bahan organik, komunitas mikroba, dan serangga air yang ada dalam kontainer itu. Selain itu, bentuk, ukuran dan letak kontainer (ada atau tidaknya penaung dari kanopi pohon atau terbuka kena sinar matahari langsung juga mempengaruhi kualitas(Barera R., 2006). Faktor curah hujan mempunyai hubungan erat dengan laju peningkatan populasi Aedes aegypti. Pada musim kemarau banyak barang bekas seperti kaleng, gelas plastik, ban bekas, dan sejenisnya yang dibuang atau ditaruh tidak teratur di sembarang tempat. Sasaran pembuangan atau penaruhan barang-barang bekas tersebut biasanya tempat terbuka, seperti lahanlahan kosong atau lahan tidur yang ada di daerah perkotaan maupun di daerah perdesaan. Ketika cuaca berubah dari musim kemarau ke musim hujan sebagian besar permukaan tanah dan barang bekas itu menjadi sarana penampung air hujan. Bila di antara tempat atau barang bekas itu berisi telur hibernasi maka dalam waktu singkat akan menetas menjadi larva Aedes aegypti yang dalam waktu (9-12 hari) menjadi imago. Fenomena lahan kosong sering menjadi tempat pembuangan sampah rumah tangga termasuk barang kaleng yang potensial sebagai tempat pembiakan nyamuk(Tavares, A.O., Mario Monteiro., M.A. Vargas., 2014).

Curah hujan dapat menambah jumlah tempat perkembangbiakan vektor (breeding places) atau dapat pula menghilangkan tempat perindukan. Curah hujan dapat juga berpengaruh terhadap suhu dan kelembaban nisbi udara. Menurut Cahyati (2006) bahwa curah hujan $140 \mathrm{~mm} /$ minggu dapat menghambat berkembangbiaknya nyamuk. Curah hujan yang lebat menyebabkan bersihnya tempat perindukan vektor oleh karena hanyut terbawa aliran air yang menyebabkan matinya larva/jentik nyamuk. Suhu mempengaruhi menetasnya larva Aedes aegypti menjadi pupa dan dewasa. Suhu yang terbaik menetaskan larva menjadi dewasa antara suhu $26^{\circ} \mathrm{C}-32^{\circ} \mathrm{C}$, bila suhu terlalu ekstrim dibawah $26^{\circ} \mathrm{C}$ atau di atas 
$32{ }^{\circ} \mathrm{C}$ maka daya penetasan larva menjadi dewasa akan menurun (Cahyati, 2006). Walaupun pada suhu $10^{\circ} \mathrm{C}$ larva. Aedes aegypti akan menetas tapi tidak begitu sempurna. Faktor suhu akan dipengaruhi oleh curah hujan pada suatu daerah, sehingga faktor iklim (curah hujan, suhu dan kelembaban udara) menjadi penting dalam penentuan pengendalian DBD (Brunkard et al., 2007). Berbagai faktor iklim terhadap DBD, dimana nyamuk dapat bertahan hidup pada suhu rendah tetapi metabolismenya menurun atau bahkan terhenti bila suhu udara turun sampai di bawah suhu kritis. Pada suhu yang lebih tinggi dari $32^{\circ} \mathrm{C}$ juga dapat mempengaruhi proses fisiologis, rata-rata suhu optimum untuk pertumbuhan nyamuk adalah $26^{\circ} \mathrm{C}-32^{\circ} \mathrm{C}$. Pertumbuhan nyamuk akan terhenti sama sekali bila suhu kurang dari $10^{\circ} \mathrm{C}$ atau lebih dari $40{ }^{\circ} \mathrm{C}$, sedangkan untuk pertumbuhan jentik diperlukan suhu udara berkisar $26{ }^{\circ} \mathrm{C}-32^{\circ} \mathrm{C}$. Kelembaban udara merupakan faktor penting dalam pertumbuhan nyamuk. Kelembaban optimal yang diperlukan untuk pertumbuhan nyamuk berkisar antara 60-80\%. Umur nyamuk Aedes aegypti betina rata-rata mencapai 10 hari. Namun, dengan keadaan suhu udara dan kelembaban yang optimal umur nyamuk dapat mencapai lebih dari 1 (satu) bulan. Secara tidak langsung kelembaban dapat berpengaruh terhadap umur nyamuk dalam kesempatannya untuk menjadi vektor. Pada kelembaban yang tinggi menyebabkan nyamuk cepat lemah dan dapat menyebabkan kematian. Pada kelembaban kurang dari 60\% umur nyamuk akan menjadi pendek sehingga tidak cukup untuk siklus pertumbuhan virus dalam tubuh nyamuk (Bouzid et al., 2014).

Penyebaran populasi Aedes aegypti erat kaitannya dengan perkembangan permukiman penduduk akibat didirikannya rumah-rumah baru yang dilengkapi sarana pengadaan dan penyimpanan air untuk keperluan seharihari. Terdapat keterkaitan antara pola/tata letak permukiman dengan perkembangan nyamuk Aedes aegypti, asumsinya bahwa pada daerah yang permukimannya padat dan tidak teratur menyebabkan kendala seperti saluran pembuangan limbah dan saluran air hujan yang tidak memadai, banyak rumah yang asal membangun sehingga tidak terdapat cukup cahaya masuk. Hal ini mengakibatkan kelembaban udara tinggi yang mempermudah perkembangbiakan nyamuk Aedes aegypti.

Berdasarkan Profil Kesehatan Jawa Tengah tahun 2013, Angka kesakitan ((Incidence Rate (IR)) DBD di Provinsi Jawa Tengah sebesar 45,52/100.000 penduduk, pada tahun 2012 sebesar 19,29/100.000 penduduk, meningkat bila dibandingkan tahun 2011 (15,27/100.000 penduduk). Angka kematian ((Case Fatality Rate (CFR)) DBD tahun 2013 sebesar 1,21\%, tahun 2012 sebesar 1,52\%, lebih tinggi dibandingkan dengan target nasional $(<1 \%)$ (Dinas Kesehatan Provinsi Jawa Tengah, 2014). Data rekapitulasi mingguan penyakit DBD di Dinas Kesehatan Kabupaten Karanganyar, jumlah kasus penderita penyakit DBD di Karanganyar melonjak pada tahun 2013 menjadi 300 kasus dan dapat dikatakan KLB (Kejadian Luar Biasa) dibanding tahun 2012 sejumlah 76 kasus. Pada tahun 2014 kejadian DBD di Kabupaten Karanganyar naik menjadi 520 kasus dengan 97 desa terjangkit dan jumlah desa terjangkit tertinggi terjadi pada bulan januari yaitu 26 desa, meskipun jumlah kejadian DBD tertinggi terjadi pada bulan juni sejumlah 92 kasus dengan 8 desa terjangkit. Kecamatan Colomadu menjadi kecamatan yang memiliki jumlah kejadian DBD tertinggi yaitu 93 kasus, dengan 55 kasus tercatat di puskesmas Colomadu I dan 38 kasus di puskesmas Colomadu II 
sedangkan Gondangrejo 88 kasus diikuti dengan Tasikmadu dan Karanganyar sebesar 74 kasus dan 68 kasus. Kecamatan Colomadu memiliki 11 desa. Kejadian DBD tertinggi terjadi di desa Malangjiwan dengan jumlah 22 kasus dan desa Gawanan 16 kasus. Kecamatan Colomadu termasuk daerah yang endemis DBD dengan 3 tahun berturut-turut memiliki jumlah kejadian DBD tertinggi dibandingkan dengan kecamatan lain (Dinas Kesehatan Kabupaten Karanganyar, 2015).

Colomadu merupakan wilayah yang endemis DBD. Faktanya, dalam 3 tahun terakhir Kecamatan Colomadu memiliki jumlah kejadian DBD tertinggi dibandingkan dengan kecamatan lain di Kabupaten Karanganyar. Penelitian terkait unsur klimatologi dan penggunaan lahan dengan DBD sudah banyak dilakukan. Namun, di Colomadu belum pernah dilakukan dan ini penting sebagai upaya kewaspadaan dini kemungkinan adanya KLB DBD. Oleh karena itu dilakukan analisis korelasi faktor curah hujan dengan kejadian DBD berbasis sistem informasi geografis untuk mengkaji faktor curah hujan terhadap kejadian DBD tahun 2010-2014 di Kabupaten Karanganyar.

\section{BAHAN DAN METODE}

Penelitian dilaksanakan di analitik dengan cara multi temporal analysis, yaitu memperoleh dan menganalisis data penginderaan jauh dengan memanfaatkan waktu perekaman yang berbeda. Obyek yang tergambar dalam citra menggambarkan kondisi dan waktu perekaman yang berbeda-beda. Dalam penelitian ini, rentang waktu kejadian DBD dan klimatologi yang dianalisis adalah tahun 2010-2014. Penelitian ini menggunakan uji statistik regresi dengan data kejadian DBD yang berasal dari Dinas kesehatan \& BPS Kabupaten Karanganyar dan data klimatologi (curah hujan) berasal dari BMKG Semarang dan Stasiun Pemantau Adi Soemarmo.

\section{HASIL}

1. Perkembangan Kejadian DBD di Kecamatan Colomadu, Kabupaten Karanganyar

Kasus DBD di Kecamatan Colomadu Minggu ke-1 hingga Minggu ke52, tertinggi berada pada tahun 2013 yaitu 167 kasus, diantaranya 74 kasus di Puskesmas Colomadu I dan 93 kasus di Puskesmas Colomadu II. Terdapat 3 desa yang paling banyak terjangkit kasus DBD yaitu Baturan sejumlah 30 kasus, Malangjiwan sejumlah 24 kasus dan Blulukan sejumlah 22 kasus. Berikut grafik jumlah kejadian DBD per desa di Kecamatan Colomadu, Kabupaten Kecamatan Colomadu. Kahunaten Karanganvar dalam 5 tahun.
Karanganyar, Provinsi Arifatun Nisaa : Korelasi Antara Faktor Curah Hujan ..... merupakan penelitian observasional

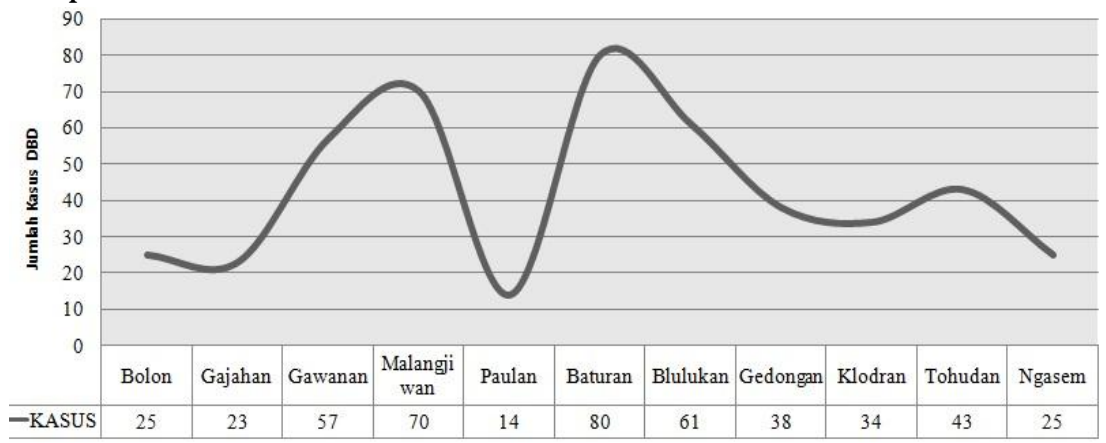




\section{Gambar 1. Grafik Distribusi Kasus DBD per desa di Kecamatan Colomadu, Kabupaten Karanganyar}

\section{Kondisi Lingkungan Fisik} Curah Hujan

Curah hujan di Kecamatan Colomadu pada bulan agustus tahun 2012 mengalami peningkatan yang signifikan yaitu 655,8 $\mathrm{mm}$ dibandingkan pada bulan sebelumnya yang hanya $0,2 \mathrm{~mm}$. Pada bulan September tahun 2011-2014 tidak terjadi hujan. Curah hujan rata-rata terendah terjadi pada tahun 2014 yaitu $141,92 \mathrm{~mm}$. Sedangkan rata-rata curah hujan tertinggi terjadi pada tahun 2012 yaitu $321,67 \mathrm{~mm}$. Gambaran curah hujan di Kecamatan Colomadu, Kabupaten Karanganyar pada periode waktu 20102014 ditunjukkan pada grafik berikut.

\begin{tabular}{|c|c|c|c|c|c|c|c|c|c|c|c|c|}
\hline \multirow{4}{*}{ 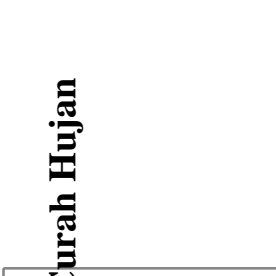 } & \multirow{2}{*}{\multicolumn{12}{|c|}{$\overline{\Longrightarrow \Longrightarrow}$}} \\
\hline & & \multicolumn{3}{|c|}{$\bar{F}=$} & & & & & & & & \\
\hline & & & & & & & & & & & & \\
\hline & 1 & 2 & 3 & 4 & 5 & 6 & 7 & 8 & 9 & 10 & 11 & 12 \\
\hline Tahun 2010 & 591 & 398,4 & $|365,7|$ & 310,5 & 407 & 94,4 & 14 & 122 & 296 & 274 & 204,3 & 400,4 \\
\hline -Tahun 2011 & 382,7 & 348,5 & 388 & 459,7 & 178 & 10,5 & 108 & 0 & 0 & 139 & 210 & 324,4 \\
\hline- Tahun 2012 & 744,1 & 688,9 & 290 & 534 & 57,9 & 70,8 & 0,2 & 655,8 & 0 & 92,2 & 309,2 & 416, \\
\hline$*$ Tah & 437 & 369 & 179,6 & 342 & 232,5 & 183,6 & 99,3 & 4,3 & 0 & 205,2 & 222 & 341,1 \\
\hline *-Tahun 2014 & 255,1 & 206,8 & 212,6 & 221,7 & 152,5 & 136,6 & 74,8 & 1,5 & 0 & 7 & 128,5 & 306 \\
\hline
\end{tabular}

Gambar 3. Grafik Curah Hujan di Kecamatan Colomadu, Kabupaten Karanganyar

\section{Korelasi Curah Hujan dengan Kejadian DBD}

Hasil uji korelasi variabel curah hujan menunjukkan nilai $r$ sebesar 0,131 yang berarti mempunyai kekuatan korelasi yang sangat lemah dan mempunyai arah korelasi yang positif. Artinya, jumlah kejadian DBD meningkat ketika curah hujan tinggi dan kejadian DBD menurun sejalan dengan menurunan curah hujan. Nilai signifikan $(p)=0,78$ sehingga dapat disimpulkan bahwa tidak ada korelasi yang bermakna antara curah hujan selama periode tahun 2010-2014 dengan kejadian DBD, karena nilai $\mathrm{p}$ lebih besar dari $\alpha(0,05)$. Dari analisis variansi (uji $F$ ), diperoleh nilai $F$ (hitung) sebesar 0,08 dengan probabilitas 0,78 lebih besar dari 0,05, yang menunjukkan tidak terdapat korelasi yang signifikan. Dari
30 Jurnal IKESMA Volume 14 Nomor 1 Maret 2018 (nilai a) sebesar 16,727 dan nilai $b=0,131$, sehingga persamaan regresinya Kasus $\mathrm{DBD}=16,727+0.131$ (curah hujan), dapat digunakan untuk memprediksi kejadian DBD, atau dengan kata lain, tidak ada korelasi antara curah hujan dengan kejadian DBD. Peningkatan curah hujan sebanding dengan peningkatan pertumbuhan jentik nyamuk DBD. Berdasarkan persamaan tersebut menunjukkan bahwa setiap peningkatan $1 \mathrm{~mm}$ curah hujan dapat memberikan perubahan peluang peningkatan kasus DBD sebesar 0,131 kasus.

\section{PEMBAHASAN}




\section{Perkembangan Kejadian DBD di Kecamatan Colomadu, Kabupaten Karanganyar}

Kasus DBD merupakan salah satu penyakit yang setiap musim penghujan (menjelang, sedang dan setelah) menjadi faktor munculnya DBD akibat lingkungan yang mendukung perkembangan jentik Aedes aegypti sebagai penyebab DBD. Perubahan iklim menyebabkan perubahan curah hujan sehingga berefek terhadap ekosistem daratan dan lautan serta berpengaruh terhadap kesehatan terutama terhadap perkembangbiakan vektor penyakit seperti nyamuk Aedes, malaria dan lainnyabaik menjelang musim maupun setelah musim hujan (Gubler, 2010).

Penularan penyakit DBD dipengaruhi oleh interaksi yang kompleks antara vektor, host dan virus. Penggunaan lahan seperti bendungan air atau praktek pertanian tertentu telah diidentifikasi sebagai faktor risiko demam berdarah karena penyediaan habitat yang cocok untuk vektor. Banyak penelitian telah difokuskan pada faktor penggunaan lahan dan tingginya jumlah vektor dengue di daerah kecil tapi belum mempelajari hubungan antara faktor-faktor penggunaan lahan dan kasus demam berdarah dengue untuk daerah besar. Penelitian Cheong et al., (2014) bertujuan untuk menjelaskan jika penggunaan lahan selain faktor pemukiman manusia, misalnya berbagai jenis penggunaan lahan pertanian, bendungan air dan hutan juga terkait dengan kasus demam berdarah dengue dilaporkan 2008-2010 di negara bagian Selangor, Malaysia. Dari study korelatif menghasilkan peta resiko prediksi. Hasil menunjukkan bahwa faktor penggunaan lahan yang paling berpengaruh adalah pemukiman manusia $(39,2 \%)$, diikuti oleh badan air $(16,1 \%)$, hortikultura campuran $(8,7 \%)$, lahan terbuka (7,5\%) dan padang rumput $(6,7 \%)$ (Cheong, Leitao and Lakes, 2014).

\section{Kondisi Lingkungan Fisik Curah Hujan}

Musim hujan dan musim kemarau memiliki pengaruh pada tingkat suhu lingkungan. Pengaruh ini cenderung bersifat lokal dengan periode waktu tertentu. Hal ini dikarenakan tingkat suhu dan kelembaban lebih kompleks dan dipengaruhi oleh fenomena global, regional dan topografi serta vegetasi. Saat pergantian musim penghujan ke musim kemarau, kondisi suhu berkisar $23^{\circ} \mathrm{C}-31^{\circ} \mathrm{C}$. Nyamuk Aedes aegypti bisa hidup pada suhu rendah tetapi metabolismenya menurun, bahkan terhenti bila suhu turun sampai dibawah suhu kritis, sebaliknya pada suhu lebih tinggi dari $35^{\circ} \mathrm{C}$ dapat mempengaruhi proses fsiologis, suhu maksimum untuk pertumbuhan nyamuk $25^{\circ} \mathrm{C}-30^{\circ} \mathrm{C}$ (WHO, 2005).

Faktor curah hujan menjadi perhatian pada penelitian ini, dimana setiap musim hujan kejadian DBD akan menjadi permasalahan yang dihadapi masyarakat. Jika curah hujan tinggi dan akhirnya terjadi banjir, maka setiap selesai kejadian banjir diikuti dengan wabah DBD. Namun, jika curah hujan kecil dan dalam waktu yang lama akan menambah tempat perindukan nyamuk dan meningkatkan populasi nyamuk. Seperti penyakit berbasis vektor lainnya, DBD menunjukkan pola yang berkaitan dengan iklim terutama curah hujan karena mempengaruhi penyebaran vektor nyamuk dan kemungkinan menularkan virus dari satu manusia ke manusia lain(Yussanti, 2010). Curah hujan yang tinggi dan berlangsung dalam waktu yang lama dapat menyebabkan banjir sehingga dapat menghilangkan tempat perindukan nyamuk Aedes aegyptiyang biasanya hidup di air bersih. Akibatnya jumlah perindukan nyamuk akan berkurang 
sehingga populasi nyamuk akan berkurang(Dini, A.M.V, 2010).

\section{Korelasi Curah Hujan dengan Kejadian DBD}

Hasil analisis dalam penelitian ini sejalan dengan penelitian Adrianto (2009) tentang hubungan antara unsur iklim dengan kejadian penyakit demam berdarah dengue di kota semarang 19992008, yang dilaksanakan pada bulan April 2009 dengan rancangan studi ekologi. Hasil uji statistik didapatkan tidak hubungan antara suhu dengan kejadian penyakit demam berdarah dengue ( $p=0,437)$ (Adrianto, 2009). Penelitian tersebut sejalan, diduga terjadi akibat adanya pengaruh faktor lain yang lebih dominan seperti adanya media perindukan nyamuk yang banyak dan perilaku masyarakat yang kurang berorientasi pada kesehatan.

Hasil uji korelasi variabel curah hujan menunjukkan nilai koefisien korelasi sebesar 0.131 yang berarti mempunyai kekuatan korelasi yang sangat lemah dan mempunyai arah korelasi yang positif. Artinya, jumlah kejadian DBD meningkat ketika curah hujan tinggi dan kejadian DBD menurun sejalan dengan menurunan curah hujan. Nilai signifikan $(p)=0.78$ sehingga dapat disimpulkan bahwa tidak ada korelasi yang bermakna antara curah hujan selama periode tahun 2010-2014 dengan kejadian DBD, karena nilai $\mathrm{p}$ lebih besar dari $\alpha$ (0.05). Dari analisis variansi (uji $F$ ), diperoleh nilai $F$ (hitung) sebesar 0.08 dengan probabilitas 0.78 lebih besar dari 0.05, yang menunjukkan tidak terdapat korelasi yang signifikan. Dari hasil uji regresi diperoleh nilai constant (nilai a) sebesar 16.727 dan nilai $b=0.131$, sehingga persamaan regresinya Kasus $\mathrm{DBD}=16.727+0.131$ (curah hujan), dapat digunakan untuk memprediksi kejadian DBD, atau dengan kata lain, tidak ada korelasi antara curah hujan dengan kejadian DBD. Peningkatan curah hujan sebanding dengan peningkatan pertumbuhan jentik nyamuk DBD. Berdasarkan persamaan tersebut menunjukkan bahwa setiap peningkatan $1 \mathrm{~mm}$ curah hujan dapat memberikan perubahan peluang peningkatan kasus DBD sebesar 0.131 kasus. Hasil penelitian ini sejalan dengan penelitian lain, bahwa tidak ada korelasi antara faktor curah hujan dengan kejadian DBD, diduga karena faktor lain yang lebih besar peranannya. Adanya curah hujan yang tinggi, memungkinkan banyak bermunculan tempat perindukan nyamuk. Namun, curah hujan tersebut dapat menyapu tempat perindukan nyamuk tersebut secara alami maupun artificial (buatan). Kondisi hujan dan panas yang berseling pada pergantian musim lebih berpengaruh positif terhadap populasi nyamuk dikarenakan air hujan tidak mengalir dan menggenang di beberapa tempat. Peningkatan jumlah media perindukan nyamuk dan semakin menurunnya daya dukung lingkungan, diduga menjadi salah satu penyebab terjadinya hubungan yang tidak bermakna tersebut.

Sebagai upaya kewaspadaan dini terhadap kemungkinan adanya KLB DBD dalam tahun-tahun berikutnya, sebaiknya dilakukan pencegahan dengan cara melepaskan nyamuk Aedes aegypti yang mengandung bakteri Wolbachia. Seperti diketahui, wolbachia adalah bakteri alami yang terdapat pada sel tubuh serangga dan ditemukan di 60 persen spesies serangga seperti rengat, lalat buah, capung, kumbang, hingga nyamuk. Namun bakteri ini tidak ada pada nyamuk Aedes aegypti yang selama ini dikenal sebagai vektor penular virus dengue. Dengan menyuntikkan bakteri wolbachia ke tubuh nyamuk, dan menyebarkan nyamuk tersebut ke daerah yang sering ditemukan kasus DBD. Harapannya dengan 
penyebaran nyamuk wolbachia ini, nyamuk penular virus dengue akan berkurang. Di sejumlah kecamatan seperti yang telah diterapkan oleh Eliminate Dengue Project (EDP) sejak 2014 lalu. Penelitian laboratorium menunjukkan keberadaan bakteri ini mampu menghambat pertumbuhan virus dengue dalam tubuh nyamuk. Dengan demikian, dapat mengurangi secara signifikan nyamuk yang dapat menyebabkan DBD. Metode ini sudah diteliti dengan melepaskan ribuan nyamuk berwolbachia di dua padukuhan, Kronggahan dan Nogotirto, Sleman. Setelah adanya pelepasan ribuan nyamuk berbakteri wolbachia, di padukuhan Kronggahan dan Nogotirto tidak ditemukan masyarakat yang terkena DBD.

\section{SIMPULAN}

1. Salah satu penyebab kejadian DDB adalah faktor curah hujan

2. Kejadian DBD tertinggi terjadi di Desa Baturan dengan jumlah 80 kasus. Suhu rata-rata di Kecamatan Colomadu $27,70 \circ \mathrm{C}$, Rata-rata kecepatan angin 5,9 $\mathrm{km} / \mathrm{jam}$, Kelembababan rata-rata $75,47 \%$, Curah hujan rata-rata $236,75 \mathrm{~mm}$, dan penggunaan lahan sebesar untuk tanah sawah $509 \mathrm{Ha}$ dan penggunaan tanah kering 1.055,17 Ha.

3. Terdapat korelasi yang bermakna kuat dengan arah positif antara curah hujan dengan kejadian DBD $(\mathrm{p}=0.56$ dan $\mathrm{r}=0.62$ ).

4. Tidak ada korelasi yang signifikan antara faktor curah hujan dengan DBD mungkin disebabkan karena kurang lamanya durasi data yang diambil, kurang lengkapnya data faktor fisik yang diperoleh dan adanya pengaruh dari faktor-faktor lain yang lebih dominan.

\section{DAFTAR RUJUKAN}

[1] Adrianto, M. (2009) Hubungan antara Unsur Iklim dengan Kejadian Penyakit DBD di Kota Semarang 1999-2008. Universitas Diponegoro.

[2] Barera R., M. A. dan G. G. C. (2006) 'Ecological Factors Influencing Aedes aegypti (Diptera: Culicidae) Productivity in Artificial Containers in Salinas, Puerto Rico', Med. Entomology, 43(3), pp. 484-492.

[3] Bouzid, M. et al. (2014) 'Climate change and the emergence of vectorborne diseases in Europe: case study of dengue fever.', BMC public health, 14, p. 781. doi: $10.1186 / 1471-2458-$ 14-781.

[4] Brunkard, J. M. et al. (2007) 'Dengue Fever Seroprevalence and Risk Factors , Texas - Mexico', Emerging Infectious Diseases, 13(10), pp. 1477-1483.

[5] Cahyati, W. H. (2006) 'Dinamika Aedes Aegypti sebagai Vektor Penyakit Kesehatan Masyarakat', 2, pp. 40-50.

[6] Cheong, Y. L., Leit Arifatun Nisaa : Korelasi Antara Fak T. (2014) 'Assessment of Land Use Factors Associated With Dengue Cases in Malaysia Using Boosted Regression Trees.', Spatial and spatio-temporal epidemiology. Elsevier Ltd, 10, pp. 75-84. doi: 10.1016/j.sste.2014.05.002.

[7] Dinas Kesehatan Kabupaten Karanganyar (2015) Profil Dinas Kesehatan Kabupaten Karanganyar 2012-2014. Karanganyar: Dinkes Kab. Karanganyar.

[8] Dinas Kesehatan Provinsi Jawa Tengah (2014) Profil Dinas Kesehatan Provinsi Jawa Tengah 2012 \& 2013. Semarang: Dinkes Prov. Jawa Tengah. 
[9] Dini, A.M.V, R. N. F. dan R. A. W. (2010) 'Faktor Iklim dan Angka Insiden Demam Berdarah Dengue di Kabupaten Serang', Jurnal Kesehatan, 14(1).

[10] Gubler (2010) The Global Threat of Emergent/re-emergen Vector-borne Diseases. In: Atkinson. Vector Bio. New York: Springer.

[11] Tavares, A.O., Mario Monteiro., M.A. Vargas., R. S. (2014) 'Land Use Change and Forest Routing in a Rural Context: The Relevance of The Community-Based Management and
Planning Framework', Applied Geography, 52, pp. 153-171. doi: 10.1016/j.apgeog.2014.05.008.

[12] WHO (2005) Panduan Lengkap Pencegahan dan Pengendalian Demam Berdarah Dengue. 1th Editio. Edited by P. Widyastuti. Jakarta: Buku Kedokteran EGC.

[13] Yussanti, N. (2010) Pemodelan Wabah DBD di Jawa Timur Berdasarkan Faktor Iklim dan Sosio Ekonomi dengan Pendekatan Regresi Panel Semi Parametrik. Institut Teknologi Surabaya. 